Article

\title{
Bioethanol Production from Biomass of Selected Sorghum Varieties Cultivated as Main and Second Crop
}

\author{
Jolanta Batog ${ }^{1}$, Jakub Frankowski ${ }^{1, *(\mathbb{D}}$, Aleksandra Wawro ${ }^{1} \mathbb{D}$ and Agnieszka Lacka ${ }^{2} \mathbb{D}$ \\ 1 Institute of Natural Fibers and Medicinal Plants, Wojska Polskiego 71B, 60-630 Poznań, Poland; \\ jolanta.batog@iwnirz.pl (J.B.); aleksandra.wawro@iwnirz.pl (A.W.) \\ 2 Poznan University of Life Sciences, Wojska Polskiego 28, 60-637 Poznań, Poland; \\ agnieszka.lacka@up.poznan.pl \\ * Correspondence: jakub.frankowski@iwnirz.pl
}

Received: 15 October 2020; Accepted: 26 November 2020; Published: 29 November 2020

\begin{abstract}
In recent years, there has been a dynamic development of alternative energy sources and the use of plant biomass for the production of bioenergy is one of the possibilities of improving the energy mix. Therefore, it is worth reaching for new, less popular and perspective solutions, which certainly include sorghum, a drought-resistant plant with a high yielding potential and various applications in the bioeconomy. The aim of the research was to determine the amount of bioethanol obtained from the biomass of three sorghum varieties (Rona 1, Santos, Sucrosorgo 506) grown in the main and second crop for three years in the temperate climate typical of Central and Eastern Europe. The yields of sorghum cultivars grown as main and second crops, chemical components of sorghum biomass (cellulose, hemicellulose, lignin) and the amount of ethanol per a ton of dry matter of straw and ethanol yield per hectare were evaluated. The experiments and research carried out show, especially in the second year, that the Sucrosorgo 506 variety can be recommended for the cultivation of biomass and its use for the production of lignocellulosic ethanol is effective, both in main and second crop cultivation. The discussed results were confirmed by detailed statistical analysis, incl. principal component analysis (PCA) and cluster analysis. To sum up, the production of bioethanol from sorghum biomass is possible in temperate climate and it does not compete with the production of food due to the possibility of growing sorghum after rye.
\end{abstract}

Keywords: sorghum varieties; main and second crop; biomass; bioethanol

\section{Introduction}

The changes of environmental and climate conditions as well as the economic growth and an increase in energy consumption have led to the intensification of research on the alternative fuels to replace fossil fuels [1,2]. One of the possibilities of improving the energy mix is the use of plant biomass for bioenergy production.

It is worth reaching for new solutions such as utilization of less popular but perspective crops, including sorghum (Sorghum L.). Sorghum is fifth in the world in terms of volume of the production after wheat, corn, rice, and barley [3]. Nowadays, sorghum is cultivated also in some European countries [4-6]. The popularity of sorghum occurs due to its drought resistance [7-9], high yield potential $[10,11]$ and various applications in the economy. This plant provides a wide range of food [12-14], industrial [15,16] and energy applications [17,18].

In comparison to corn, sorghum is able to withstand a long period without precipitation, often with almost no damage to plants. The collected data indicate that $80 \%$ of sorghum production in the world is 
under dryland conditions [19]. Changing climatic conditions have been observed in European countries for several years. Drought in combination with very high temperatures are favorable conditions for sorghum development.

One of the main possibilities for the economic use of sorghum biomass is bioenergy production. Its biomass can be used for pellets and briquettes formation. These products are efficient solid biofuels because they are characterized by high calorific value $[20,21]$. In addition, stems and grain of sorghum can be effective substrates for bioethanol production [22]. In turn, straw shives or residues from biomass processing are useful for biogas production [23-25]. Most of the studies described in articles concern using the sorghum biomass from tropical and subtropical areas [26-28]. For that reason, there is a lack of knowledge regarding the energy potential of sorghum straw harvested in a temperate climate.

Lignocellulosic biomass is the most widely known biomass in the world and can be found in the leaves, skins and branches of many plants. Therefore, the production of lignocellulosic bioethanol in recent years is an alternative for the still frequently used starch bioethanol. Lignocellulosic bioethanol does not compete with food production for raw materials, and moreover, it contributes to a much greater reduction of greenhouse gases emission. This type of bioethanol is particularly suitable for countries where agricultural and forestry waste is used as input materials [29].

Lignocellulose is a complex structure found in plants and consists of cellulose, hemicellulose, lignin and other extracts and mineral traces. Lignin plays an important role in cross-linking of cellulose and hemicellulose. Due to these properties of lignin, the whole structure is more durable and resistant to external hydrolyzing agents, which in the case of bioethanol production is a significant obstacle. Hence, an important step in the production of bioethanol from plant biomass is the pretreatment to remove lignin and increase the potential for hydrolyzing agents. It is well known that the production of bioethanol from plant biomass involves deconstruction of cell walls to individual polymers and next hydrolysis of carbohydrates to monosaccharides [30].

The sorghum biomass conversion process to bioethanol consists of three main stages. The first step is biomass preparation through the use of physicochemical pretreatment. Milling as the physical method, is aimed at to reduce the size of the substrate as well as to facilitate the access of bioactive substances to the surface, reduction of polymerization and crystallization degree of lignocellulose. In turn, chemical processes include among others acid and base treatments [31,32]. Depending on the method used, various changes take place within the lignocellulosic complex, e.g., alkaline and neutral pretreatment is basically a delignification process, while the acid and steam treatment dissolves most of the hemicellulose. The second step is enzymatic hydrolysis, using enzymatic preparations, which allows the release of fermentable sugars. Ethanol fermentation is the last stage in which monosaccharides are converted to ethanol by various microorganisms, including the yeast Saccharomyces cerevisiae Meyen ex E.C. Hansen [33].

The authors, based on previous study on the process of obtaining bioethanol from sorghum biomass, general concluded that sorghum biomass may be a valuable raw material for obtaining lignocellulosic bioethanol [34]. Moreover, no literature has been published before in relation to possibility of effective cultivation of sorghum as a second crop and utilization its biomass for bioethanol production above 50 degrees north latitude. Therefore, the aim of this presented research is made to determine the yield of bioethanol produced from three varieties of sorghum in the main and secondary crops, which can be grow in temperate climate typical of Central and Eastern Europe.

\section{Materials and Methods}

\subsection{Sorghum Biomass}

The raw materials used in the study were three varieties of sorghum biomass: Sucrosorgo 506, Santos and Rona 1 (AgriSem GmbH, Einbeck, Germany). The field research was conducted in a three-year period in Stary Sielec in Poland $\left(51^{\circ} 39^{\prime} \mathrm{N}, 17^{\circ} 10^{\prime} \mathrm{E}\right)$ in the Experimental Farm of the Institute of Natural Fibers and Medicinal Plants. 
The experiments were carried out on a soil characterized by abundance of nutrients and medium agricultural usefulness. The plots were located next to the last position annually, but not in the same place to avoid the monoculture. The forecrop was rye, which was harvested in the milk-wax phase of seed maturity for animal feed or harvested for grain, depending on the cultivation variant provided for sorghum. There were two terms of sorghum sowing accordingly: in mid-May (as a main crop) and in the end of June (as a second crop). Sorghum seeds were sown at the following level of fertilization (in kg.ha- ${ }^{-1}$ ): $120 \mathrm{~N}, 60 \mathrm{P}_{2} \mathrm{O}_{5}, 100 \mathrm{~K}_{2} \mathrm{O}$ and $30 \mathrm{MgO}$ in the amount of $10 \mathrm{~kg} \cdot \mathrm{ha}^{-1}$. The surface of the experimental plot was $50 \mathrm{~m}^{2}$ each and for every variety it was repeated four times a year. The cultivation was carried out in accordance with the principles of good agricultural practice. The row spacing was $40 \mathrm{~cm}$. After sowing, the herbicide Afalon was applied in the amount of $1 \mathrm{~kg} \cdot \mathrm{ha}^{-1}$. Since plants have shown a few green sprouts, no chemical plant protection products were used. The weeds were removed mechanically at the initial stage of growth.

During the growing season, the dates of sowing, germination, appearance of stems, panicles, flowering were noted. Under the climatic conditions of Greater Poland, the tested varieties do not produce fully mature seeds. The number of plants for $1 \mathrm{~m}^{2}$ in each plot was measured after sowing and immediately before harvesting. Also, the height of randomly selected 10 plants in each plot was checked before harvesting. Sorghum was harvested in the last days of September, in the early stages of seed maturity, onset of the first autumn frost. During the biomass harvest, sorghum straw samples were collected from each plot. Then, a reference amount of raw material was taken from the mixed samples of each variety to obtain and determine bioethanol.

\subsection{Bioethanol Production Process}

\subsubsection{Pretreatment}

The chemical pretreatment of the sorghum biomass was performed by using $1.5 \%$ sodium hydroxide after $5 \mathrm{~h}$ treatment at $90{ }^{\circ} \mathrm{C}$. After a 5 -h incubation, the process was stopped by filtration of the biomass suspension under reduced pressure. The filtered biomass was rinsed with portions of distilled water until a neutral $\mathrm{pH}$ was reached. The filtrate prepared in this way was used as a substrate in enzymatic hydrolysis and ethanol fermentation.

\subsubsection{Enzymatic Hydrolysis}

In a subsequent step enzymatic hydrolysis of the sorghum biomass was carried out. Flashzyme Plus 200 (AB Enzymes, Darmstadt, Germany) in an amount of $30 \mathrm{FPU} \mathrm{g}^{-1}$ was added to the $10 \%$ hydrolysate. The process was carried out at $50^{\circ} \mathrm{C}$, for $72 \mathrm{~h}$, at a pH value of 4.2 .

\subsubsection{Ethanol Fermentation}

The sorghum biomass after enzymatic hydrolysis was sterilized by autoclaving in $121{ }^{\circ} \mathrm{C}$ for $15 \mathrm{~min}$ and used as a fermentation medium. The medium was inoculated with Saccharomyces cerevisiae cells from the inoculum culture $\left(1 \times 10^{7} \mathrm{cfu} / \mathrm{mL}\right)$.

S. cerevisiae Meyen ex E.C. Hansen yeast (commercial strain Ethanol Red) was obtained from Lessafre Fermentis (Lille, France). The microorganisms were stored on yeast extract peptone dextrose (YPD) medium with the addition of $1 \%$ yeast extract $(w / v), 2 \%$ peptone $(w / v), 2 \%$ glucose $(w / v)$ and $2 \%$ $(w / v)$ agar-agar kept at the temperature of $4-8{ }^{\circ} \mathrm{C}$.

The fermentation process was performed in a $250 \mathrm{~mL}$ Erlenmeyer flask and incubated in a rotary shaker at $140 \mathrm{rpm}$ for $120 \mathrm{~h}$ at $37^{\circ} \mathrm{C}$, and $\mathrm{pH}$ value 4.8 , with fermentation tubes. The prepared hydrolysate was adjusted to the desired $\mathrm{pH}$ with $10 \%$ sulfuric acid and $10 \%$ sodium hydroxide.

\subsection{Analytical Methods}

The chemical components of sorghum biomass were evaluated i.e., cellulose acc. to TAPPI T17 $\mathrm{m}-55$, hemicellulose as the difference holocellulose acc. to TAPPI T9 m-54 and cellulose, as well as 
lignin acc. to TAPPI T13 m-54 [35-37], moisture by the dried (gravimetric) method, and ash according to Tappi DIN 51,731 [38].

The content of ethanol concentration was determined by high performance liquid chromatography (HPLC, Agilent Technologies 1200, Santa Clara (California), USA). For this purpose, a Rezex ROA column (Phenomenex, Aschaffenburg, Germany) was used, at $40{ }^{\circ} \mathrm{C}$, in $0.005 \mathrm{~N} \mathrm{H}_{2} \mathrm{SO}_{4}$, as an eluent at the flow rate of $0.6 \mathrm{~mL} \cdot \mathrm{min}^{-1}$.

\subsection{Calculations}

Ethanol yield from $100 \mathrm{~g}$ of raw material $\mathrm{Y}_{\mathrm{s}}(\mathrm{g} / 100 \mathrm{~g}$ of raw material) was calculated according to the Equation (1) [39]:

$$
\mathrm{Y}_{\mathrm{S}}=(\mathrm{Et} \times 100) / \mathrm{M}
$$

where: Et—amount of ethanol in $1000 \mathrm{~mL}$ of tested sample (g), M-mass of material weighed in $1000 \mathrm{~mL}$ fermentation sample $(\mathrm{g})$.

Then, based on the ethanol yield from $100 \mathrm{~g}$ of raw material, the amount of ethanol in $\mathrm{L}$ per ton of straw dry matter $\left(\mathrm{L} \cdot \mathrm{Mg}^{-1}\right)$ was calculated, and on the basis of straw yield, the ethanol yield per hectare $\left(\mathrm{m}^{3} \cdot \mathrm{ha}^{-1}\right)$ was determined.

\subsection{Statistical Analysis}

All experiments, both for main and second crop were carried out in a completely randomized design with four independent repetitions. The Shapiro-Wilk W-test was used to test for normality. If the hypothesis of normality was not rejected, an analysis of variance (ANOVA) was performed and Tukey's post hoc test was used. Otherwise, the nonparametric Kruskal-Wallis (K-W) rank sum test and multiple comparisons of mean ranks were calculated. $p$-values indicating whether the general hypothesis tests are statistically significant were marked with a standard significance code ${ }^{* * *}$ for a significance level of $0.001 ;{ }^{* *}$ for a significance level of $0.01 ; *$ for a significance level of 0.05 ).

General sample testing using the principal component analysis (PCA procedure) was done by a singular value decomposition of the scaled data matrix.

In order to measure the relationships between the observed variables, Pearson's correlation coefficients were determined for the linear association and Spearman's rank correlations were determined for the monotonic association. The strength of the correlation was described using a scale suggested by Evans [40]. Statistical analysis was performed using R software ( $R$ version 3.5.2, Microsoft Corporation, Washington (District of Columbia) USA). It should be added that PCA analysis used yield and bioethanol data for fresh and dry straw mass.

\section{Results and Discussion}

\subsection{Sorghum Biomass Yield}

\subsubsection{Straw Dry Matter Yield}

The data and analysis of sorghum dry matter yield showed significant differences between average straw yields in all years of the study, both in the experiments carried out for the main and second crops (Tables 1 and 2).

Table 1. Descriptive statistics (mean, standard error) for straw dry matter yield of sorghum $\left(\mathrm{Mg} \cdot \mathrm{ha}^{-1}\right)$.

\begin{tabular}{ccccccc}
\hline \multirow{2}{*}{ Variety } & \multicolumn{2}{c}{ Year I } & \multicolumn{2}{c}{ Year II } \\
& \multicolumn{7}{c}{ Crop } \\
& \multicolumn{1}{c}{ Main } & Second & Main & Second & Main & Second \\
\cline { 2 - 6 } & $27.40( \pm 0.78)$ & $24.25( \pm 0.43)$ & $27.53( \pm 0.78)$ & $31.05( \pm 0.75)$ & $21.05( \pm 0.37)$ & $8.25( \pm 0.32)$ \\
Rona 1 & $29.85( \pm 0.92)$ & $24.80( \pm 0.39)$ & $32.10( \pm 1.3)$ & $29.88( \pm 0.57)$ & $18.95( \pm 0.1)$ & $9.23( \pm 0.29)$ \\
Santos & $32.00( \pm 0.33)$ & $36.80( \pm 0.87)$ & $47.18( \pm 1.6)$ & $32.68( \pm 0.38)$ & $20.45( \pm 0.63)$ & $10.80( \pm 0.51)$ \\
Sucrosorgo 506 & & & & & & \\
\hline
\end{tabular}


Table 2. Statistical analysis of sorghum straw dry matter yield $\left(\mathrm{Mg} \cdot \mathrm{ha}^{-1}\right)$.

\begin{tabular}{ccccccc}
\hline & \multicolumn{3}{c}{ Main Crop } & \multicolumn{3}{c}{ Second Crop } \\
\cline { 2 - 7 } & Year I & Year II & Year III & Year I & Year II & Year III \\
\hline Type of Analysis & ANOVA & K-W & ANOVA & K-W & ANOVA & ANOVA \\
\hline df & $2 ; 9$ & 2 & $2 ; 9$ & 2 & $2 ; 9$ & $2 ; 9$ \\
F/ $\chi^{2}$ & 10.15 & 9.846154 & 6.392 & 7.883333 & 5.765 & 11.25 \\
$p$-value & $0.00493^{* *}$ & $0.007276706^{* *}$ & $0.0187^{*}$ & $0.01941583^{*}$ & $0.0245^{*}$ & $0.00356^{* *}$ \\
\hline \multicolumn{7}{c}{ Mean Values for Treatments/Results of Post Hoc Tests $\boldsymbol{\alpha}=\mathbf{0 . 0 5}$} \\
\hline General mean & 29.75 & 35.60 & 20.15 & 28.62 & 31.20 & 9.43 \\
Rona 1 & $27.40^{\mathrm{b}}$ & $27.53^{\mathrm{c}}$ & $21.05^{\mathrm{a}}$ & $24.25^{\mathrm{b}}$ & $31.05^{\mathrm{ab}}$ & $8.25^{\mathrm{b}}$ \\
Santos & $29.85^{\mathrm{ab}}$ & $32.10^{\mathrm{b}}$ & $18.95^{\mathrm{b}}$ & $24.80^{\mathrm{b}}$ & $29.88^{\mathrm{b}}$ & $9.23^{\mathrm{b}}$ \\
Sucrosorgo 506 & $32.00^{\mathrm{a}}$ & $47.18^{\mathrm{a}}$ & $20.45^{\mathrm{ab}}$ & $36.80^{\mathrm{a}}$ & $32.68^{\mathrm{a}}$ & $10.80^{\mathrm{a}}$ \\
\hline
\end{tabular}

** for a significance level of 0.01 ; $*$ for a significance level of 0.05 ; abc values with differing small letters within the same column are significantly different $(p<0.05)$.

For both sorghum yield cultivated as a main and second crop, the highest overall average dry masses were obtained in the second year of the study. In both experiments, Sucrosorgo 506 variety was the best, in the case of which the average yield for the main crop $\left(47.175 \mathrm{Mg} \cdot \mathrm{ha}^{-1}\right)$ differed significantly from the average yields of other varieties, while in the case of the second crop, significant differences were found only between the average weight for the Sucrosorgo 506 cultivar $\left(32.676 \mathrm{Mg} \cdot \mathrm{ha}^{-1}\right.$ ) and the Santos cultivar $\left(29.875 \mathrm{Mg} \cdot \mathrm{ha}^{-1}\right)$. Also, in the first and third year of research, the Sucrosorgo 506 variety allowed to obtain significantly higher efficiency as a second crop compared to the other two varieties. The lowest main straw yield in the first two years of research was obtained for Rona 1 variety while in the third year this variety yielded best. Most of the research on sorghum biomass yield have been done in tropical and sub-tropical climates [41-43]. That is why it is difficult to compare the obtained results with worldwide research. It should be additionally explained that in the third year of testing an extreme drought appeared, especially in autumn, which usually caused a significant reduction in the yields $[4,9]$. However, the results presented in this article show that sorghum cultivation and effective bioethanol production from its biomass is possible in temperate climate just like in the southern hemisphere. Its biomass harvested as a second crop may be also useful for biogas production [23,44]. Moreover, its cultivation does not compete with the production of food due to the possibility of growing sorghum after cereals like rye (Secale cereale L.) or winter wheat (Triticum aestivum L.) in Kansas [45].

\subsubsection{Chemical Composition of Sorghum Biomass}

Subsequently, determination of the chemical composition (cellulose, hemicellulose, lignin and ash) of sorghum biomass was performed (Table 3).

The average moisture of the samples of all analyzed sorghum varieties was $7.8 \%$, and the extractives content including ash content was $5.9 \%$. Ash content is an important factor that affects the yield of bioethanol production. The requirement for ash content of raw material for bioethanol production is not more than $10 \%$. When the ash content is too high, it can inhibit the fermentation process and cause damage to the equipment during the distillation process.

The analysis of the chemical composition of individual sorghum varieties showed that in years II and III the content of cellulose, hemicellulose and lignin was higher than in year I for both the main and the second crop.

In the main crop, the highest cellulose content was determined in the Santos (35.6\%) and Sucrosorgo $506(35.2 \%)$ cultivars in year II, and in the second crop for the Santos variety in all three years, i.e., $32.9 \%$ (year II), 32.1\% (year III) and 30.2\% (year I). Cultivar Rona 1 in year II, especially cultivated as a main crop $(41.2 \%)$ and as a second crop $(34.0 \%)$, was characterized by the highest hemicellulose content, as well as the Sucrosorgo $506(38.5 \%)$ in second term of sowing in year III of the plot experiment. The lowest values of lignin were determined in the sorghum biomass from year I of analysis for the 
cultivars Sucrosorgo 506 and Rona 1, both as a main (18.2\% for both cultivars) and as a second crop (16.8\% and $17.4 \%$, respectively). Moreover, the biomass of the Santos variety from three-year research period showed a slightly higher lignin content than the Sucrosorgo 506 and the Rona 1 varieties as a main and second crop.

Table 3. Chemical composition of sorghum biomass for the main and second crop.

\begin{tabular}{ccccccc}
\hline \multirow{2}{*}{ Variety } & \multicolumn{2}{c}{ Year I } & \multicolumn{2}{c}{ Year II } & \multicolumn{2}{c}{ Year III } \\
\cline { 2 - 7 } & \multicolumn{7}{c}{ Crop } \\
\cline { 2 - 7 } & Main & Second & Main & Second & Main & Second \\
\hline & \multicolumn{7}{c}{ Cellulose (\%) } \\
\hline Rona 1 & 29.4 & 21.9 & 31.1 & 23.2 & 34.6 & 25.8 \\
Santos & 32.5 & 30.2 & 35.6 & 32.9 & 34.7 & 32.1 \\
Sucrosorgo 506 & 30.1 & 24.8 & 35.2 & 29.0 & 32.8 & 27.0 \\
\hline & & \multicolumn{7}{c}{ Hemicelluose (\%) } \\
\hline Rona 1 & 21.2 & 25.7 & 34.0 & 41.2 & 29.4 & 35.6 \\
Santos & 28.2 & 26.8 & 32.7 & 31.1 & 32.8 & 31.2 \\
Sucrosorgo 506 & 26.8 & 31.4 & 31.1 & 36.4 & 32.9 & 38.5 \\
\hline & & \multicolumn{7}{c}{ Lignin (\%) } \\
\hline Rona 1 & 18.2 & 17.4 & 20.2 & 19.3 & 19.2 & 18.3 \\
Santos & 19.3 & 19.9 & 20.9 & 21.5 & 20.2 & 20.8 \\
Sucrosorgo 506 & 18.2 & 16.8 & 20.6 & 19.0 & 19.4 & 17.9 \\
\hline
\end{tabular}

\subsection{Bioethanol Production}

\subsubsection{Bioethanol Yield per Ton}

The bioethanol yield $\left(\mathrm{L} \cdot \mathrm{Mg}^{-1}\right.$ of sorghum straw dry matter) in the main crop was higher than the ethanol yield as a second crop by an average of 9\%, the highest percentage for the Sucrosorgo 506 variety (average 11.7\%), the lowest for the Rona 1 variety (average 6.4\%) (Table 4).

Table 4. Bioethanol yield from sorghum straw $\left(\mathrm{L} \cdot \mathrm{Mg}^{-1}\right.$ of straw DM).

\begin{tabular}{ccccccc}
\hline \multirow{2}{*}{ Variety } & \multicolumn{2}{c}{ Year I } & \multicolumn{2}{c}{ Year II } & \multicolumn{2}{c}{ Year III } \\
\cline { 2 - 7 } & \multicolumn{9}{c}{ Crop } \\
\cline { 2 - 7 } & Main & Second & Main & Second & Main & Second \\
\hline Rona 1 & 430 & 403 & 456 & 425 & 506 & 474 \\
Santos & 243 & 223 & 266 & 240 & 258 & 235 \\
Sucrosorgo 506 & 413 & 365 & 484 & 428 & 451 & 397 \\
\hline
\end{tabular}

The highest ethanol yield was obtained in the third year for cultivar Rona 1 and amounted to $506 \mathrm{~L} \cdot \mathrm{Mg}^{-1}$ as a main crop and $474 \mathrm{~L} \cdot \mathrm{Mg}^{-1}$ as a second crop, and then for cultivar Sucrosorgo 506 in the secondary year in the main crop $\left(484 \mathrm{~L} \cdot \mathrm{Mg}^{-1}\right)$ and as a second crop $\left(428 \mathrm{~L} \cdot \mathrm{Mg}^{-1}\right)$. Additionally, in each year Sucrosorgo 506 and Rona 1 cultivars showed much higher values of derived ethanol yield than Santos cultivar, which may be related to the higher content of lignin in the biomass of this sorghum variety.

\subsubsection{Bioethanol Yield per Hectare}

Tables 5 and 6 show bioethanol yields from sorghum straw per hectare. 
Table 5. Descriptive statistics (mean, standard error) for bioethanol yield per hectare from sorghum straw $\left(\mathrm{m}^{3} \cdot \mathrm{ha}^{-1}\right)$.

\begin{tabular}{ccccccc}
\hline \multirow{2}{*}{ Variety } & \multicolumn{2}{c}{ Year I } & \multicolumn{2}{c}{ Year II } & \multicolumn{2}{c}{ Year III } \\
\cline { 2 - 7 } & \multicolumn{5}{c}{ Crop } \\
\cline { 2 - 6 } & Main & Second & Main & Second & Main & Second \\
\hline Rona 1 & $11.78( \pm 0.34)$ & $9.77( \pm 0.17)$ & $12.55( \pm 0.36)$ & $13.20( \pm 0.32)$ & $10.65( \pm 0.19)$ & $3.91( \pm 0.15)$ \\
Santos & $7.26( \pm 0.23)$ & $5.53( \pm 0.09)$ & $8.54( \pm 0.35)$ & $7.17( \pm 0.14)$ & $4.89( \pm 0.03)$ & $2.17( \pm 0.07)$ \\
Sucrosorgo 506 & $13.22( \pm 0.13)$ & $13.43( \pm 0.32)$ & $22.84( \pm 0.77)$ & $13.99( \pm 0.16)$ & $9.22( \pm 0.29)$ & $4.87( \pm 0.23)$ \\
\hline
\end{tabular}

Table 6. Statistical analysis of bioethanol yield per hectare from sorghum straw.

\begin{tabular}{|c|c|c|c|c|c|c|}
\hline & \multicolumn{3}{|c|}{ Main Crop } & \multicolumn{3}{|c|}{ Second Crop } \\
\hline & Year I & Year II & Year III & Year I & Year II & Year III \\
\hline & \multicolumn{6}{|c|}{ General Analysis-Results } \\
\hline Type of Analysis & $\mathrm{K}-\mathrm{W}$ & K-W & K-W & K-W & K-W & ANOVA \\
\hline $\mathrm{df}$ & 2 & 2 & 2 & 2 & 2 & $2 ; 9$ \\
\hline $\mathrm{F} / \mathrm{c}^{2}$ & 9.880702 & 9.846154 & 9.880702 & 9.846154 & 9.269231 & 71.11 \\
\hline \multirow[t]{2}{*}{$p$-value } & $0.007152088^{* *}$ & $0.007276706^{* *}$ & $0.007152088^{* *}$ & $0.007276706^{* *}$ & $0.009709841^{* *}$ & $3.06 \times 10^{-6 * * *}$ \\
\hline & \multicolumn{6}{|c|}{ Mean Values for Treatments/Results of Post Hoc Tests $\alpha=0.05$} \\
\hline General mean & 10.75 & 14.64 & 8.25 & 9.58 & 11.45 & 3.65 \\
\hline Rona 1 & $11.78^{\mathrm{b}}$ & $12.55^{\mathrm{b}}$ & $10.65^{\mathrm{a}}$ & $9.77^{b}$ & $13.20^{\mathrm{b}}$ & $3.91^{\mathrm{b}}$ \\
\hline Santos & $7.26^{\mathrm{c}}$ & $8.54^{\mathrm{c}}$ & $4.89^{c}$ & $5.53^{c}$ & $7.17^{c}$ & $2.17^{\mathrm{c}}$ \\
\hline Sucrosorgo 506 & $13.22^{\mathrm{a}}$ & $22.84^{\mathrm{a}}$ & $9.22^{b}$ & $13.43^{\mathrm{a}}$ & $13.99^{\text {a }}$ & $4.87^{\mathrm{a}}$ \\
\hline
\end{tabular}

*** for a significance level of 0.001 ; ** for a significance level of 0.01 ; abc values with differing small letters within the same column are significantly different $(p<0.05)$.

The average bioethanol yield both for sorghum cultivated as a main and second crop differs significantly for the tested varieties. During three years of research in experiments dealing with second crop, analogous rankings of bioethanol yield for individual varieties were obtained. The highest average yield of bioethanol was estimated for Sucrosorgo 506 variety at $13.4325 \mathrm{~m}^{3} \cdot \mathrm{ha}^{-1}$ and $13.985 \mathrm{~m}^{3} \cdot \mathrm{ha}^{-1}$ in the first and second year of testing respectively and $4.8725 \mathrm{~m}^{3} \cdot \mathrm{ha}^{-1}$ in the last year, in which (as in the case of the observed straw crop) the obtained bioethanol yield was much lower than in the first two years of the study.

For the main crop, the average yield of bioethanol obtained in the first and second year of research for Sucrosorgo 506 variety was significantly higher than the average for the other varieties. In the second year of research, an average of $22.835 \mathrm{~m}^{3} \cdot \mathrm{ha}^{-1}$ of bioethanol was obtained for this cultivar, followed by Rona 1 cultivar (in terms of bioethanol yield) with an average of $45 \%$ lower and Santos cultivar with an average of $62 \%$ lower than Sucrosorgo 506 cultivar.

For all of the cultivars, the average bioethanol in the last year of research was lower than for those in the first and second year of research. Again, it is worth paying attention to Rona 1 variety, which seems to be the most resistant one to the changing weather conditions both in terms of straw yield and bioethanol yield per hectare. In the third year of the main crop study, this variety achieved significantly higher bioethanol yield compared to Sucrosorgo 506 variety (on average 13\% lower than Rona 1) and Santos variety (54\% lower).

The Roozeboom et al. [46] conducted research on the long-term comparison of annual crops and perennial raw materials for the production of cellulosic ethanol, among others switchgrass, miscanthus, grain sorghum and maize. They observed that some annual straw crops showed $7 \mathrm{Mg} \cdot \mathrm{ha}^{-1}$ more straw crop than compared to long-term crops over 11 years. The best result was obtained for sorghum, the straw crop was $22 \mathrm{Mg} \cdot \mathrm{ha}^{-1}$, while the ethanol yield was $12 \mathrm{~m}^{3} \cdot \mathrm{ha}^{-1}$. In turn, the ethanol yield for maize as a combined raw material for the production of first and second generation biofuels was on average over $7 \mathrm{~m}^{3} \cdot \mathrm{ha}^{-1}$, with biomass yield of $17.4 \mathrm{Mg} \cdot \mathrm{ha}^{-1}$. Thus, the average ethanol yield for sorghum exceeds that for other lignocellulosic raw materials. 
In turn, Ekefre team [47] conducted a three-year field study to evaluate three sorghum varieties as

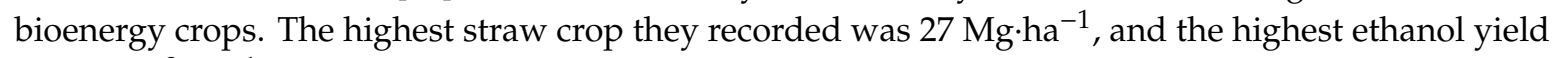
was $7.7 \mathrm{~m}^{3} \cdot \mathrm{ha}^{-1}$.

\subsection{Bioethanol Yield, Chemical Composition and Yield of Sorghum Biomass-Relationship}

A strong or very strong positive linear relationship between bioethanol production efficiency $(\mathrm{BPE})$ and cellulose as well as a very strong $\left(\mathrm{cr}_{\mathrm{p}}>0.96\right)$ linear relationship between straw dry mass yield and bioethanol was confirmed for all tested cultivars (Figure 1).

\begin{tabular}{lcccccc}
\multicolumn{7}{c}{ RONA 1 } \\
\hline & SDY & BPH & C & HC & L & BPT \\
SDY & - & 0.94 & -0.14 & 0.20 & 0.49 & -0.54 \\
BPH & 0.97 & - & 0.14 & 0.26 & 0.66 & -0.26 \\
C & -0.03 & 0.18 & - & -0.14 & 0.49 & 0.83 \\
HC & -0.07 & -0.04 & -0.23 & - & 0.66 & 0.14 \\
L & 0.31 & 0.46 & 0.55 & 0.55 & - & 0.37 \\
BPT & -0.52 & -0.31 & 0.78 & 0.17 & 0.45 & -
\end{tabular}

\begin{tabular}{lcccccc}
\multicolumn{7}{c}{ SANTOS } \\
\hline & SDY & BPH & C & HC & L & BPT \\
SDY & - & 0.94 & 0.54 & -0.09 & 0.37 & 0.49 \\
BPH & 0.98 & - & 0.49 & -0.14 & 0.09 & 0.54 \\
C & 0.24 & 0.40 & - & 0.77 & 0.49 & 0.94 \\
HC & -0.16 & 0.00 & 0.87 & - & $0, .3$ & 0.71 \\
L & -0.04 & 0.01 & 0.32 & 0.62 & - & 0.20 \\
BPT & 0.29 & 0.45 & 0.99 & 0.80 & 0.19 & -
\end{tabular}

\begin{tabular}{lcccccc}
\multicolumn{7}{c}{ SUCROSORGO 506} \\
\hline & SDY & BPH & C & HC & L & BPT \\
SDY & - & 0.94 & 0.20 & -0.54 & 0.26 & 0.26 \\
BPH & 0.96 & - & 0.31 & -0.43 & 0.43 & 0.43 \\
C & 0.34 & 0.55 & - & -0.43 & 0.94 & 0.94 \\
HC & -0.57 & -0.50 & -0.29 & - & -0.20 & -0.20 \\
L & 0.34 & 0.56 & 0.95 & -0.04 & - & 1.00 \\
BPT & 0.33 & 0.55 & 0.98 & -0.10 & 1.00 & -
\end{tabular}

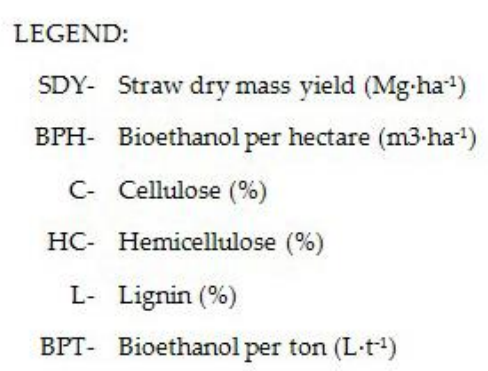

Figure 1. Combined matrices of Pearson correlation coefficients $\mathrm{cr}_{\mathrm{p}}$ (lower left) and Spearman rank correlation coefficients $\mathrm{cr}_{\mathrm{s}}$ (upper right) for the chemical composition and yield of tested varieties.

For Santos variety, a strong relationship was found between bioethanol production efficiency and hemicellulose $\left(\mathrm{cr}_{\mathrm{p}}=0.8\right.$ and $\left.\mathrm{cr}_{\mathrm{s}}=0.71\right)$, no similar relationship was found for Sucrosorgo 506 and Rona 1 cultivars. For both Rona 1 and Sucrosorgo 506 cultivars, a correlation between BPE and lignin content was explained; it was moderate for Rona 1 cultivar $\mathrm{cr}_{\mathrm{p}}=0.45$ and very strong for Sucrosorgo $506 \mathrm{cr}_{\mathrm{p}}=0.995$. A moderate negative relationship between straw dry mass yield and hemicellulose was found for Sucrosorgo 506 variety $\left(\mathrm{cr}_{\mathrm{p}}=-0.57\right.$ and $\left.\mathrm{cr}_{\mathrm{s}}=-0.54\right)$; no analogous relationship was obtained for Rona 1 and Santos varieties. A very strong positive linear relationship was found between the lignin and cellulose $\left(\mathrm{cr}_{\mathrm{p}}=0.95\right)$ for Sucrosorgo 506 variety, for Rona variety the correlation was moderate $\left(\mathrm{cr}_{\mathrm{p}}=0.55\right)$.

\subsection{Principal Component Analysis (PCA)}

PCA analysis explained $72.8 \%$ of total variability of samples to observed variables. The grouping of points representing the individual experimental cases due to the interesting parameters allowed to illustrate the relationship between varieties and sowing dates (Figure 2). 

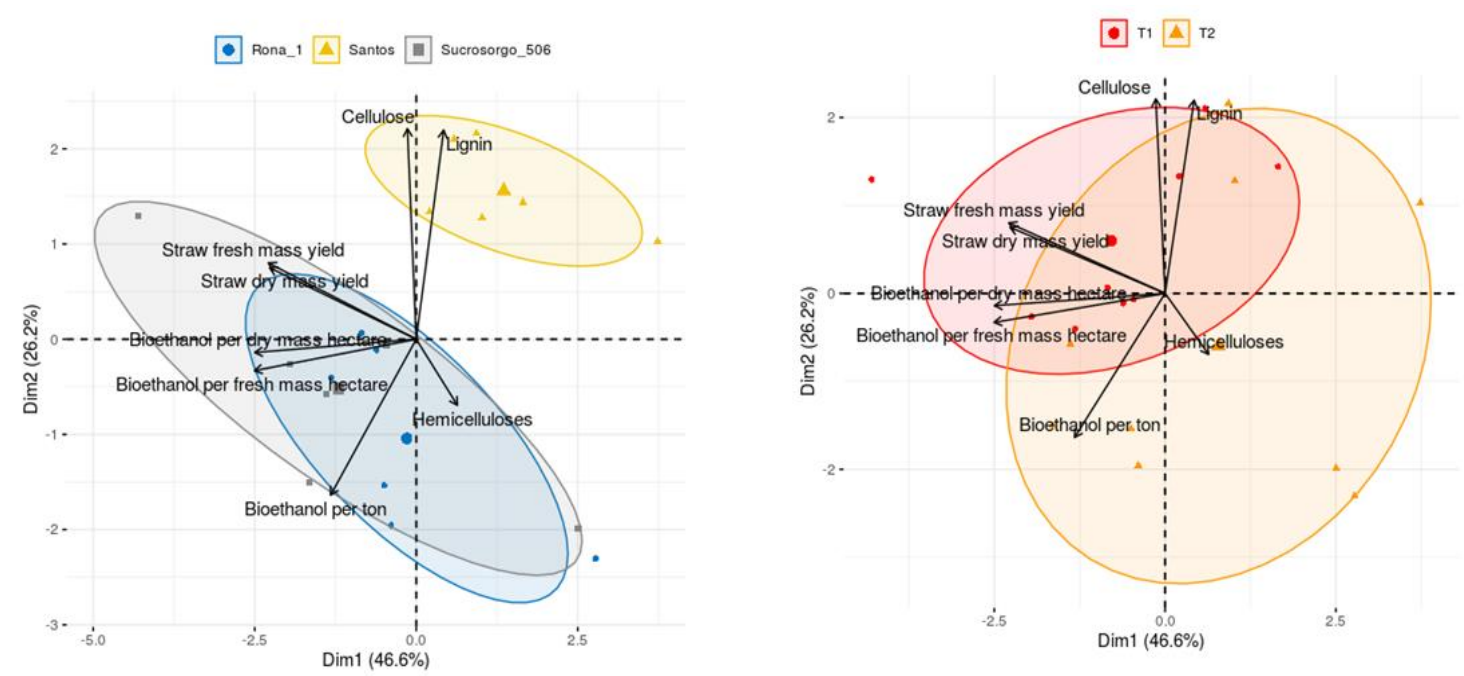

Figure 2. Principal component analysis of tested sorghum cultivars, cases grouped by the cultivars and term. Ellipsoids indicate $67 \%$ confidence. (T1-main crop; T2-second crop).

Figure 2 shows the distinct of Santos variety and the similarity of Rona 1 and Sucrosorgo 506 varieties. However, no clear differences can be found between sowing dates, which corresponds to similar trends in the ranking of varieties in terms of straw dry matter yield and bioethanol yield per hectare (Tables 1 and 4 ).

Based on the vectors of loadings relative to the first two principal components, a very strong positive correlation can be found between the bioethanol productivity in fresh and dry mass and between fresh and dry straw mass as well as a strong correlation between bioethanol productivity and straw mass, because the chemical composition affects the energy potential of biomass [48], which was also observed in other researches in this area [17,49-51].

A positive correlation was also found for lignin and cellulose. The coordinates of the points for Santos variety indicate higher than average overall lignin and cellulose content. The opposite tendency was observed for the other varieties, with the values obtained in the main crop being closer to the general average [52-54].

\section{Conclusions}

Based on the obtained results it can be concluded that Rona 1 and Sucrosorgo 506 straw had higher ethanol values harvested as a main and also second crops compared to Santos variety, while for all of the three tested cultivars higher amounts of ethanol per ton from the main crop than from the second crop were observed. Experiments and statistical analysis of the results showed that Santos variety is different from the other analyzed sorghum varieties.

Moreover, on the basis of the study concluded that Sucrosorgo 506 is the most effective cultivar for the production of lignocellulosic ethanol in both periods of cultivation. Furthermore, Rona 1 was characterized by the highest resistance to drought as a main crop, both in terms of yield and the amount of obtained bioethanol.

The production of bioethanol from sorghum biomass is possible in temperate climate and it does not compete with the production of food due to the possibility of growing sorghum after rye.

The results of study indicate the possibility of effective sorghum cultivation as a second crop and utilization of its biomass for the bioethanol production. However, techno-economic analysis should be performed to popularize the sorghum cultivation in Central and Eastern Europe.

Due to breeding progress, new sorghum varieties, which give fully matured grains in a temperate climate, have already appeared. Therefore, it is planned to determine in the future the effectiveness of obtaining bioethanol from waste biomass of this sorghum cultivars after deseeding. 
Author Contributions: Conceptualization, J.B., J.F., A.W.; methodology, J.B., J.F., A.W., A.Ł.; software, A.Ł.; validation, J.B., J.F., A.W., A.Ł.; formal analysis, J.B., J.F., A.W.; investigation, J.F., A.W.; resources, J.F., A.W.; data curation, J.B., J.F.; writing-original draft preparation J.B., J.F., A.W., A.Ł.; writing-review and editing, J.B., J.F., A.W., A.Ł.; visualization, J.B., J.F.; supervision, project administration and funding acquisition, J.B., J.F. All authors have read and agreed to the published version of the manuscript.

Funding: This research received no external funding.

Conflicts of Interest: The authors declare no conflict of interest.

\section{References}

1. Bhattacharya, M.; Paramati, S.R.; Ozturk, I.; Bhattacharya, S. The effect of renewable energy consumption on economic growth: Evidence from top 38 countries. Appl. Energy 2016, 162, 733-741. [CrossRef]

2. Inglesi-Lotz, R. The impact of renewable energy consumption to economic growth: A panel data application. Energy Econ. 2016, 53, 58-63. [CrossRef]

3. Dicko, M.H.; Gruppen, H.; Traoré, A.S.; Voragen, A.G.; Van Berkel, W.J. Sorghum grain as human food in Africa: Relevance of content of starch and amylase activities. Afr. J. Biotechnol. 2006, 5, 384-395.

4. Przybylska-Balcerek, A.; Frankowski, J.; Stuper-Szablewska, K. The influence of weather conditions on bioactive compound content in sorghum grain. Eur. Food Res. Technol. 2020, 246, 13-22. [CrossRef]

5. Przybylska-Balcerek, A.; Frankowski, J.; Stuper-Szablewska, K. Bioactive compounds in sorghum. Eur. Food Res. Technol. 2019, 245, 1075-1080. [CrossRef]

6. Prażak, R. Prospects for Sorghum cultivation in Poland. Acta Agrobot 2016, 69, 1661. [CrossRef]

7. Guo, Y.Y.; Tian, S.S.; Liu, S.S.; Wang, W.Q.; Sui, N. Energy dissipation and antioxidant enzyme system protect photosystem II of sweet sorghum under drought stress. Photosynthetica 2018, 56, 861-872. [CrossRef]

8. Badigannavar, A.; Teme, N.; de Oliveira, A.C.; Li, G.; Vaksmann, M.; Viana, V.E.; Sarsu, F. Physiological, genetic and molecular basis of drought resilience in sorghum [Sorghum bicolor (L.) Moench]. Indian J. Plant. Physiol. 2018, 23, 670-688. [CrossRef]

9. Nxele, X.; Klein, A.; Ndimba, B.K. Drought and salinity stress alters ROS accumulation, water retention, and osmolyte content in sorghum plants. S. Afr. J. Bot. 2017, 108, 261-266. [CrossRef]

10. Clarke, S.J.; McLean, J.; George-Jaeggli, B.; McLean, G.; de Voil, P.; Eyre, J.X.; Rodriguez, D. Understanding the diversity in yield potential and stability among commercial sorghum hybrids can inform crop designs. Field Crops Res. 2019, 230, 84-97. [CrossRef]

11. Thomas, H.L.; Pot, D.; Latrille, E.; Trouche, G.; Bonnal, L.; Bastianelli, D.; Carrère, H. Sorghum biomethane potential varies with the genotype and the cultivation site. Waste Biomass Valorization 2019, 10, 783-788. [CrossRef]

12. Anunciação, P.C.; de Morais Cardoso, L.; Gomes, J.V.P.; Della Lucia, C.M.; Carvalho, C.W.P.; Galdeano, M.C.; Pinheiro-Sant'Ana, H.M. Comparing sorghum and wheat whole grain breakfast cereals: Sensorial acceptance and bioactive compound content. Food Chem. 2017, 221, 984-989. [CrossRef] [PubMed]

13. Trappey, E.F.; Khouryieh, H.; Aramouni, F.; Herald, T. Effect of sorghum flour composition and particle size on quality properties of gluten-free bread. Food Sci. Technol. Int. 2015, 21, 188-202. [CrossRef] [PubMed]

14. Althwab, S.; Carr, T.P.; Weller, C.L.; Dweikat, I.M.; Schlegel, V. Advances in grain sorghum and its co-products as a human health promoting dietary system. Food Res. Int. 2015, 77, 349-359. [CrossRef]

15. Nghiem, N.P.; Montanti, J.; Johnston, D.B. Sorghum as a renewable feedstock for production of fuels and industrial chemicals. AIMS Bioeng. 2016, 3, 75-91. [CrossRef]

16. Dahlberg, J.; Berenji, J.; Sikora, V.; Latković, D. Assessing sorghum [Sorghum bicolor (L.) Moench] germplasm for new traits: Food, fuels \& unique uses. Maydica 2012, 56, 86-92.

17. Szambelan, K.; Nowak, J.; Frankowski, J.; Szwengiel, A.; Jeleń, H.; Burczyk, H. The comprehensive analysis of sorghum cultivated in Poland for energy purposes: Separate hydrolysis and fermentation and simultaneous saccharification and fermentation methods and their impact on bioethanol effectiveness and volatile by-products from the grain and the energy potential of sorghum straw. Bioresour. Technol. 2018, 250, 750-757.

18. Regassa, T.H.; Wortmann, C.S. Sweet sorghum as a bioenergy crop: Literature review. Biomass Bioenergy 2014, 64, 348-355. [CrossRef] 
19. Assefa, Y.; Staggenborg, S.A.; Prasad, V.P.V. Grain sorghum water requirement and responses to drought stress: A review. Crops Manag. 2010, 9,1-11. [CrossRef]

20. Serra, P.; Colauzzi, M.; Amaducci, S. Biomass sorghum production risk assessment analysis: A case study on electricity production in the Po Valley. Biomass Bioenergy 2017, 96, 75-86. [CrossRef]

21. Serra, P.; Giuntoli, J.; Agostini, A.; Colauzzi, M.; Amaducci, S. Coupling sorghum biomass and wheat straw to minimise the environmental impact of bioenergy production. J. Clean. Prod. 2017, 154, 242-254. [CrossRef]

22. Almodares, A.; Hadi, M.R. Production of bioethanol from sweet sorghum: A review. Afr. J. Agric. Res. 2009, 4, 772-780.

23. Wannasek, L.; Ortner, M.; Amon, B.; Amon, T. Sorghum, a sustainable feedstock for biogas production? Impact of climate, variety and harvesting time on maturity and biomass yield. Biomass Bioenergy 2017, 106, 137-145. [CrossRef]

24. Zhang, Z.; Zhang, G.; Li, W.; Li, C.; Xu, G. Enhanced biogas production from sorghum stem by co-digestion with cow manure. Int. J. Hydrog. Energy 2016, 41, 9153-9158. [CrossRef]

25. Windpassinger, S.; Friedt, W.; Frauen, M.; Snowdon, R.; Wittkop, B. Designing adapted sorghum silage types with an enhanced energy density for biogas generation in temperate Europe. Biomass Bioenergy 2015, 81, 496-504. [CrossRef]

26. De Almeida, L.G.F.; da Costa Parrella, R.A.; Simeone, M.L.F.; de Oliveira Ribeiro, P.C.; dos Santos, A.S.; da Costa, A.S.V.; Schaffert, R.E. Composition and growth of sorghum biomass genotypes for ethanol production. Biomass Bioenergy 2019, 122, 343-348. [CrossRef]

27. Davila-Gomez, F.J.; Chuck-Hernandez, C.; Perez-Carrillo, E.; Rooney, W.L.; Serna-Saldivar, S.O. Evaluation of bioethanol production from five different varieties of sweet and forage sorghums (Sorghum bicolor (L.) Moench). Ind. Crops Prod. 2011, 33, 611-616. [CrossRef]

28. Barcelos, C.A.; Maeda, R.N.; Betancur, G.J.V.; Pereira, N., Jr. Ethanol production from sorghum grains [Sorghum bicolor (L.) Moench]: Evaluation of the enzymatic hydrolysis and the hydrolysate fermentability. Braz. J. Chem. Eng. 2011, 28, 597-604. [CrossRef]

29. Rivera-Burgos, L.A.; Volenec, J.J.; Ejeta, G. Biomass and bioenergy potential of brown midrib sweet sorghum germplasm. Front. Plant. Sci. 2019, 10, 1142. [CrossRef]

30. An Tran, T.T.; Phung, L.T.K.; Thanh Phong, M.; Nguyen, D.Q. Bioethanol production from lignocellulosic biomass. In Alcohol Fuels—Current Technologies and Future Prospect; Yun, Y., Ed.; IntechOpen: London, UK, 2019; pp. 65-78.

31. Kumar, A.K.; Sharma, S. Recent updates on different methods of pretreatment of lignocellulosic feedstocks: A review. Bioresour. Bioprocess. 2017, 4, 7. [CrossRef]

32. Asgher, M.; Ahmad, Z.; Iqbal, H.M.N. Alkali and enzymatic delignification of sugarcane bagasse to expose cellulose polymers for saccharification and bioethanol production. Ind. Crops Prod. 2013, 44, 488-495. [CrossRef]

33. Rosales-Calderon, O.; Arantes, V. A review on commercial-scale high-value products that can be produced alongside cellulosic ethanol. Biotechnol. Biofuels 2019, 12, 240. [CrossRef] [PubMed]

34. Cellulose in Wood; TAPPI 17 m-55; TAPPI Press: Atlanta, GA, USA, 1955.

35. Holocellulose in Wood; TAPPI T9 m-54; TAPPI Press: Atlanta, GA, USA, 1998.

36. TAPPI T13 m-54. Lignin in wood-Determination of lignin in non-wood plant fiber sources. J. Tech. Associ. Pulp Pap. Ind. 1971, 54, 11.

37. Batog, J.; Wawro, A. Process of obtaining bioethanol from sorghum biomass using genome shuffling. Cellul. Chem. Technol. 2019, 53, 459-467. [CrossRef]

38. Testing of Solid Fuels, Compressed Untreated Wood. Requirements and Testing; TAPPI DIN 51731; DIN CERTCO: Berlin, Germany, 1996.

39. Kawa-Rygielska, J.; Pietrzak, W. Zagospodarowanie odpadowe pieczywa do produkcji bioetanolu. Żywność Nauka Technol. Jakość 2011, 79, 105-118.

40. Evans, J.D. Straightforward Statistics for the Behavioral Sciences; Thomson Brooks/Cole Publishing Co., University of California: Oakland, CA, USA, 1996.

41. Mundia, C.W.; Secchi, S.; Akamani, K.; Wang, G. A regional comparison of factors affecting global sorghum production: The case of North America, Asia and Africa's Sahel. Sustainability 2019, 11, 2135. [CrossRef]

42. Hadebe, S.T.; Modi, A.T.; Mabhaudhi, T. Drought tolerance and water use of cereal crops: A focus on sorghum as a food security crop in sub-Saharan Africa. J. Agron. Crops Sci. 2017, 203, 177-191. [CrossRef] 
43. Zougmoré, R.; Mando, A.; Ringersma, J.; Stroosnijder, L. Effect of combined water and nutrient management on runoff and sorghum yield in semiarid Burkina Faso. Soil Use Manag. 2003, 19, 257-264. [CrossRef]

44. Carcedo, A.J.; Gambin, B.L. Sorghum drought and heat stress patterns across the Argentinean temperate central region. Field Crops Res. 2019, 241, 107552. [CrossRef]

45. Schlegel, A.J.; Assefa, Y.; Haag, L.A.; Thompson, C.R.; Holman, J.D.; Stone, L.R. Yield and soil water in three dryland wheat and grain sorghum rotations. Agron. J. 2017, 109, 227-238. [CrossRef]

46. Roozeboom, K.L.; Wang, D.; McGowan, A.R.; Propheter, J.L.; Staggenborg, S.A.; Rice, C.W. Long-term biomass and potential ethanol yields of annual and perennial biofuel crops. Agron. J. 2018, 110, 74-83. [CrossRef]

47. Ekefre, D.E.; Mahapatra, A.K.; Latimore, M., Jr.; Bellmer, D.D.; Jena, U.; Whitehead, G.J.; Williams, A.L. Evaluation of three cultivars of sweet sorghum as feedstocks for ethanol production in the Southeast United States. Heliyon 2017, 3, 1-18. [CrossRef] [PubMed]

48. Frankowski, J.; Zaborowicz, M.; Dach, J.; Czekała, W.; Przybył, J. Biological waste management in the case of a pandemic emergency and other natural disasters determination of bioenergy production from floricultural waste and modeling of methane production using deep neural modeling methods. Energies 2020, 13, 3014. [CrossRef]

49. Szambelan, K.; Nowak, J.; Szwengiel, A.; Jeleń, H. Quantitative and qualitative analysis of volatile compounds in sorghum distillates obtained under various hydrolysis and fermentation conditions. Ind. Crops Prod. 2020, 155, 112782. [CrossRef]

50. Szambelan, K.; Nowak, J.; Szwengiel, A.; Jeleń, H. A water-saving fermentation process for sorghum grain: The effect of re-using stillage liquid part on ethanol efficiency and volatile compounds. J. Clean. Prod. 2020, 121830. [CrossRef]

51. Szambelan, K.; Nowak, J.; Szwengiel, A.; Jeleń, H. Comparison of sorghum and maize raw distillates: Factors affecting ethanol efficiency and volatile by-product profile. J. Cereal Sci. 2020, 91, 102863. [CrossRef]

52. Mardia, K.V.; Kent, J.T.; Bibby, J.M. Multivariate Analysis; Academic Press: London, UK, 1979.

53. Krzanowski, W.J. Selection of variables to preserve multivariate structure, using principal components. Appl. Stat. 1987, 36, 22-33. [CrossRef]

54. Jolliffe, I.T.; Cadima, J. Principal component analysis: A review and recent developments. Philos. Trans. R. Soc. A 2016, 374, 20150202. [CrossRef]

Publisher's Note: MDPI stays neutral with regard to jurisdictional claims in published maps and institutional affiliations.

(C) 2020 by the authors. Licensee MDPI, Basel, Switzerland. This article is an open access article distributed under the terms and conditions of the Creative Commons Attribution (CC BY) license (http://creativecommons.org/licenses/by/4.0/). 